\title{
ANALISIS MANAJEMEN PEMBINAAN OLAHRAGA PRESTASI DI KONI PEMATANG SIANTAR
}

\author{
Oleh: \\ Mesnan', Freddy Antonius ${ }^{1}$ \\ ${ }^{1}$ Fakultas Ilmu Keolahragaan, Universitas Negeri Medan \\ Email: freddyantonius21@gmail.com
}

\begin{abstract}
Abstrak
Penelitianini bertujuan untuk melihat Analisis Manajemen Pembinaan Olahraga Prestasi di KONI Pematang Siantar. Metode yang digunakan dalam penelitian ini adalah metode deskriptif dengan teknik survei dengan menggunakan angket,jumlah populasi dalam penelitian ini adalah 162 orang dan sample penelitian adalah 30 orang,kemudian dilakukan penyebaran angket dilokasi penelitian. Dari hasil penyebaran agket,setelah dianalisis dengan teknik persentase menunjukkan bahwa Manajemen Pembinaan Olahraga Prestasi yang dilakukan oleh Komite Olahraga Nasional Indonesia Pematang Siantar dikatagorikan baik sekali dengan persentase rata-rata sebesar 81,18\% (sangat baik), dan persentase berdasarkan 4 (empat) fungsi manajemen yaitu perencanaan (planning) sebesar 71,9\% (baik), pengorganisasian (organizing) sebesar 78,89\% (baik), penggerakan (actuating) sebesar $85 \%$ (sangat baik), pengendalian (controlling) sebesar $88,93 \%$ (sangat baik). Dalam pembinaan olahraga prestasi terdapatbeberapa faktor lainnya yang mempengaruhi prestasi pada KONI Pematang Siantar yaitu sumber dana yang terbatas karna hanya mengandalkan dari APBD dan sarana prasarana yang tersedia masih terbatas karna masih meminjam prasarana dari pihak kota Pematang Siantar Dengan demikian dapat disimpulkan bahwa manajemen olahraga prestasi yang dilakukan oleh Komite Olahraga Nasional Indonesia Pematang Siantar memiliki katagori "baik".
\end{abstract}

Kata Kunci : Manajemen, Pembinaan, Olahraga, Prestasi

\section{A. PENDAHULUAN}

Olahraga adalah setiap aktivitas yang mengandung sifat atau ciri permainan dan melibatkan unsur perjuangan mengendalikan diri sendiri atau orang lain atau konfirmasi dengan faktor alam(Rosdiani, 2012:61). Olahraga menyebabkan perbaikan dalam tubuh yang mempengaruhi seluruh aspek kehidupan seharian seseorang. Pendekatan holistik tubuh/ jiwa termasuk pula penekanan pada ketiga domain kependidikan, yakni: psikomotor, kognitif, dan afektif. Dengan meminjam ungkapan Gensemmer, pendidikan jasmani diistilahkan sebagai proses menciptakan "tubuh yang baik bagi tempat pikiran atau jiwa”. Artinya dalam tubuh yang baik diharapkan pula terdapat jiwa yang sehat, sejalan dengan pepatah Romawi Kuno, "men sano in corpore sano”. Sehingga setiap manusia yang sering melakukan kegiatan olahraga akan memiliki kesehatan rohani dan 
jasmani yang lebih baik dibandingkan manusia yang jarang atau tidak pernah melakukan kegiatan olahraga.

Definisi olahraga yang dirumuskan dewan Eropa (1980) dalam Nugroho (2012:1) "olahraga sebagai aktivitas spontan, bebas dan dilaksanakan selama waktu luang". Pengertian ini merupakan interpretasi yang masih bersifat umum yang kemudian digunakan sebagai dasar bagi gerakan "Sport Of All". Dari pengertian olahraga ini memberikan keluasan melakukan aktivitas olahraga sebagai suatu aktivitas olahraga yang tidak mengandung pengertian kompetitif.

Selain itu seiring dengan perkembangan olahraga, olahraga juga digunakan sebagai sarana untuk mengangkat harkat dan martabat. Hal tersebut dapat dicapai melalui prestasi yang membanggakan dibidang olahraga. Untuk mencapai tujuan tersebut, di Indonesia telah ada satu organisasi keolahragaan nasional yang berwenang mengkoordinasikan dan membina setiap dan seluruh kegiatan olahraga prestasi. Organisasi yang dimaksud adalah Komite Olahraga Nasional Indonesia (KONI) yang mempunyai tujuan untuk mewujudkan prestasi olahraga yang membanggakan, membangun watak bangsa untuk mengangkat harkat dan martabat bangsa Indonesia (KONI, 2014:3).

Untuk mendapatkan tujuan tersebut, KONI mempunyai susunan organisasi tersebut, berkewajiban untuk melaksanakan tugas dan kewajibannya sesuai Anggaran Dasar/ mulai dari tingkat kecamatan sampai tingkat pusat. Rangkaian susunan pemimpin KONI Anggaran Rumah Tangga (AD/ART) dan keputusan lain yang mengikat seperti Musornas, Raparnas, Musorda Musda dan Raparda serta KEPRES RI No.72 tahun 2001 pasal 2 bahwa KONI bertugas membantu pemerintah dalam menetapkan kebijaksanaan nasional di bidang pembinaan dan pengembangan olahraga prestasi, baik amatir maupun profesional. Mengoordinasikan dan membina kegiatan olahraga prestasi yang pelaksanaannya dilakukan oleh organisasi-organisasi induk cabang olahraga yang bersangkutan. Melaksanakan dan mengoordinasikan keikutsertaan induk-induk cabang olahraga dalam multievent nasional, regional, dan internasional. Melaksanakan evaluasi dan pengawasan untuk mencapai konsistensi antara kebijaksanaan dan pelaksanaan.

Berdasarkan pada latar belakang sebagai dasar pertimbangan pelaksanaan penelitian dan rumusan masalah, maka tujuan dapat dikemukakan: 
1. Untuk memperoleh gambaran manajemen perencanaan pembinaan olahraga presatasi dalam organisasi di KONI Pematang siantar, meliputi aspek penyusunan program kerja, perencanaan pembinaan prestasi, perencanaan anggaran dan perencanaan sarana dan prasarana.

2. Untuk memperoleh gambaran manajemen pengorganisasian olahraga presatasi dalam organisasi KONI Pematang siantar, meliputi koordinasi dan kerja sama pengurus kabupaten dalam pembentukan induk cabang olahraga.

3. Untuk memperoleh gambaran manajemen pelaksanaan pembinaan olahraga prestasi dalam organisasi KONI Pematang siantar, meliputi pembinaan atlet dan keikutsertaan kejuaraan/pertandingan.

4. Untuk memperoleh gambaran manajemen pengawasan dalam pembinaan olahraga prestasi dalam organisasi KONI Pematang siantar, meliputi aspek pengawasan, monitoring, dan evaluasi.

Manajemen secara umum didefinisikan sebagai "kemampuan atau keterampilan untuk memeroleh suatu hasil dalam rangka pencapaian tujuan melalui kegiatan-kegiatan orang lain” (Siagian 2005: 62). Menurut Miller (dalam Pasau 1999: 39) manajemen adalah proses memimpin dan melancarkan pekerjaan dari orang-orang yang terorganisir secara formal sebagai kelompok untuk mencapai tujuan yang diinginkan. Manajemen dan administrasi tidak menjalankan sendiri-sendiri kegiatannya yang bersifat organisasional, tetapi bersama-sama berada dalam satu gerak dan langkah. Siagian (dalam Paturusi, 2012: 72) mengaskan pada proses administrasi fungsi-fungsi lebih bersifat general dan berlaku bagi seluruh organisasi. Sedangkan pada proses manajemen fungsi-fungsi lebih bersifat departemental atau sektoral. Fungsi adalah kegiatan atau tugas-tugas yang harus dikerjakan dalam usaha mencapai tujuan. Dilihat adanya beberapa aspek utama masalah manajemen yaitu perencanaan (planning), pengorganisasian (organizing), pelaksanaan (actuating), dan pengawasan, monitoring dan evaluasi. Keempat fungsi tersebut akan dijelaskan sebagai berikut:

a. Manajemen Perencanaan

Perencanaan adalah penentuan lebih awal tujuan yang ingin dicapai dan alat-alat yang digunakan untuk mencapai tujuan itu, (Husdarta 2012: 37). Perencanaan itu mencakup apa yang dilakukan, bagaimana melakukan, dan siapa 
yang akan melakukannya. Karena selalu ada anggapan antara apa yang telah dicapai dan apa yang dituju, maka evaluasi dibutuhkan.

b. Manajemen Pengorganisasian

Menurut Narayanan dan Nath (dalam Harsuki 2013: 105) mengartikan organisasi merupakan suatu arena dimana manusia bekerjasama guna melaksanakan tugas yang kompleks untuk mencapai tujuannya. Jadi, pengertian organisasi lebih berfokus pada upaya untuk mengaktualkan dan mengkoordinasikan kerjasama antara individu untuk mencapai tujuan yang telah ditetapkan.

c. Manajemen Penggerakan

Pergerakan dapat didefinisikan sebagai keseluruhan usaha, cara, teknik, dan metode untuk mendorong para anggota organisasi agar mau dan ikhlas bekerja dengan sebaik mungkin demi tercapainya tujuan organisasi dengan efisien, efektif dan ekonomis.

d. Manajemen pengawasan monitoring dan evaluasi

Menurut Manualang (2012: 173) pengawasan dapat diartikan sebagai suatu proses untuk menerapkan pekerjaan apa yang sudah dilaksanakan, menilainya, dan bila perlu mengoreksi dengan maksud supaya pelaksanaan pekerjaan sesuai dengan rencana semula. Dalam melaksanakan kegiatan controlling, seorang pemimpin mengadakan pemeriksaan serta mengusahakan agar kegiatan-kegiatan yang dilaksanakan sesuai rencana yang telah ditetapkan serta tujuan yang ingin dicapai.

\section{B. METODOLOGI PENELITIAN}

Sesuai dengan judul penelitian ini, maka peneliti mengambil lokasi penelitian di Komite Olahraga Nasional (KONI) Pematang siantar. Penelitian ini dilaksanakan pada bulan Mei 2018. Menurut Sudjana (1996:6) populasi adalah totalitas semua nilai yang mungkin, hasil meghitung dan pengukuran, kuantitatif dan kualitatif mengenai karakteristik sesuatu dari semua anggota kumpulan yang lengkap dan jelas dan ingin dipelajari sifat-sifatnya. Maka yang menjadi populasi dalam penelitian ini adalah seluruh staf Komite Olaharaga Nasional Indonesia Pematang Siantar yang berjumlah 162 orang. Menurut Sudjana (1996:6) "sampel adalah sebagian dari keseluruhan objek yang menjadi populasi yang dapat dianggap dapat mewakili seluruh populasi”. Pengambilan sampel dilakukan dengan metode purposive sampling. Pada penelitian ini 
pengambilan sampel dilakukan dengan metode purposive sampling, dengan batasan sebagai berikut :

1. Staf Komite Olaharaga Nasional Indonesia Pematang siantar

2. Jumlah responden 30 orang staf Komite Olaharaga Nasional Indonesia di Pematang siantar.

Penelitian ini merupakan penelitian deskriptif dengan teknik survei menggunakan angket. Penggunaan metode observasi dalam penelitian deskriptif bertujuan untuk mengumpulkan data sebanyak-banyaknya tentang manajemen pembinaan olahraga prestasi yang dilakukan oleh KONI Pematang siantar. Setelah semua data yang diambil dalam suatu penelitian terkumpul, langkah selanjutnya adalah menganalisis data yang terkumpul tersebut. Sehingga nantinya dapat ditarik kesimpulan melalui penghitungan data tersebut. Mengingat penelitian ini bersifat deskriptif kualitatif, maka data-data yang dihasilkan dianalisis menggunakan teknik analisis statistik.

Menurut Arikunto (2002) menyatakan, teknik penghitungan dalam angket menggunakan presentase yang kemudian ditafsirkan kedalam bentuk kalimat yang menggambarkan kuantitas dari data tersebut.Teknik analisis data mencari besarnya frekuensi relatif menggunakan rumus :

$$
\mathrm{p}=\frac{F}{n} \times 100 \%
$$

Setelah diperoleh data melalui analisis data, kemudian diklarifikasikan kedalam aspek penilaian.
a. $76 \%-100 \%$
= Baik sekali
b. $56 \%-75 \%$
$=$ Baik
c. $41 \%-74 \%$
= Kurang
d. Kurang dari $40 \%$
= Kurang sekali

\section{HASIL DAN PEMBAHASAN PENELITIAN}

\section{HASIL PENELITIAN}

Dari hasil validasi, angket manajemen pembinaan olahraga prestasi di- susun berdasarkan beberapa indikator yaitu: Perencanaan yang terdiri dari 7 item, Pengorganisasian yang terdiri dari 6 item, Pergerakan terdiri dari 5 item dan Pengendalian terdiri dari 7 item. Dari hasil penyebaran angket yang disebarkan di KONI Pematang Siantar diperoleh hasil dengan kategori "Baik sekali". 


\section{Tabel 1}

Hasil angket analisis manajemen pembinaan olahraga prestasi di KONI Pematang Siantar.

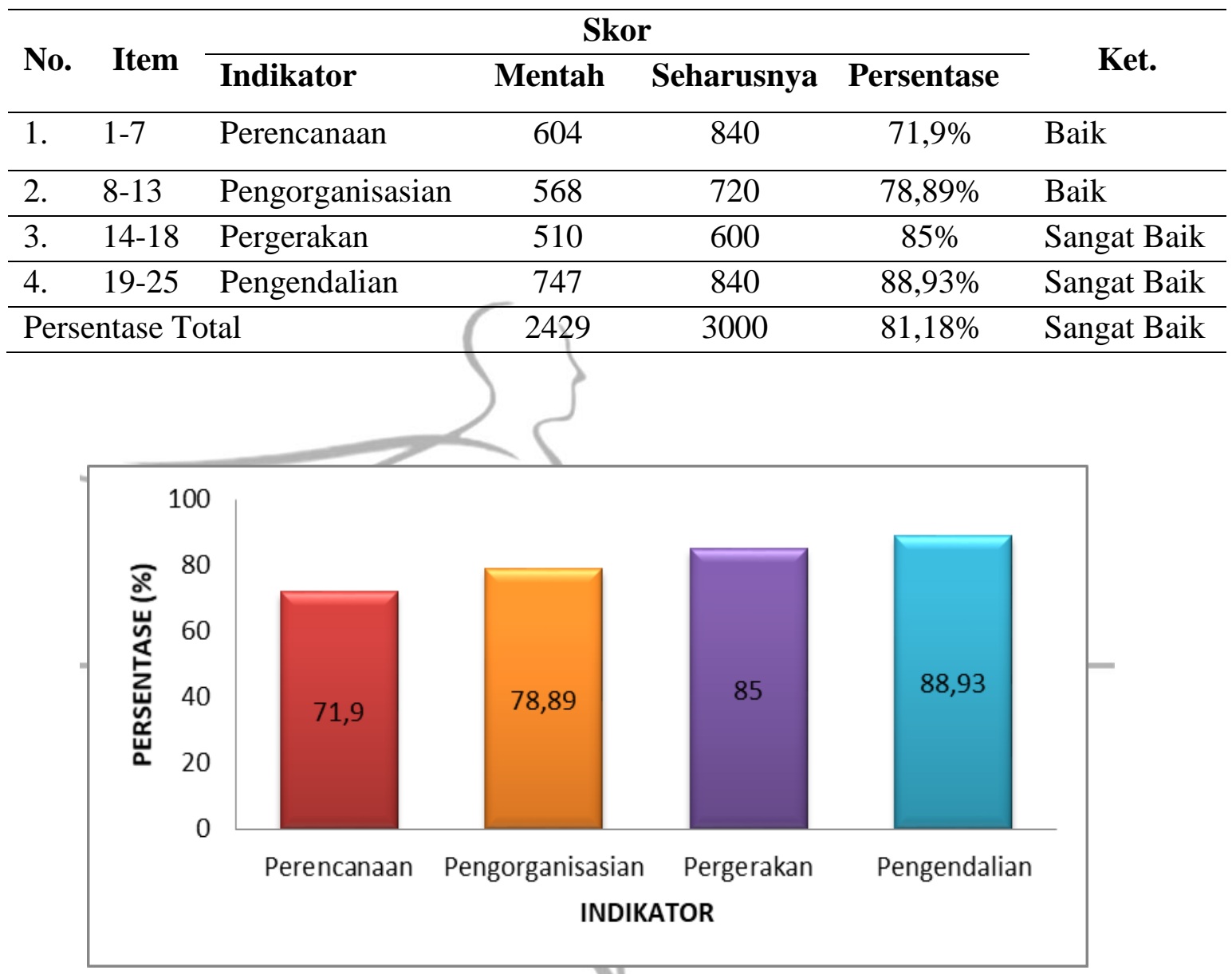

Gambar 1. Grafik Hasil Analisis Manajemen Olahraga Prestasi di KONI Pematang Siantar

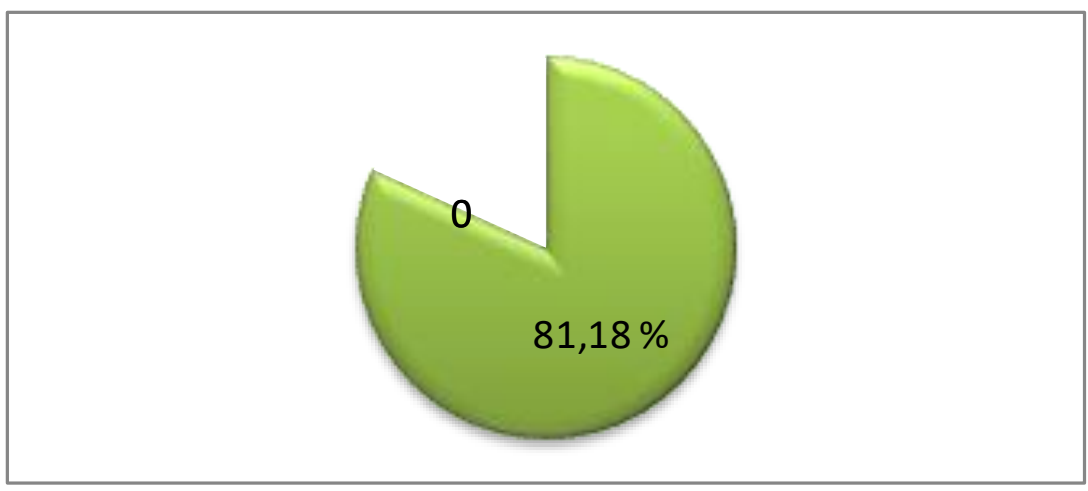

Gambar 2. Persentase Manajemen Olahraga Prestasi di KONI Pematang Siantar Berdasarkan 4 Indikator 
a. Analisis Deskriptif Manajemen Perencanaan KONI Pematang Siantar

Tabel 2

Deskripsi Tanggapan Responden Terhadap Manajemen Perencanaan

\begin{tabular}{cccc}
\hline $\begin{array}{c}\text { JUMLAH } \\
\text { RESPONDEN }\end{array}$ & $\begin{array}{c}\text { JUMLAH ITEM } \\
\text { PERNYATAAN }\end{array}$ & TOTAL SKOR & $\begin{array}{c}\text { PERSENTASE } \\
(\boldsymbol{\%})\end{array}$ \\
\hline 30 & 7 & 604 & 71,9 \\
\hline
\end{tabular}

Berdasarkan tabel di atas rangkuman rekapitulasi hasil deskriptif frekuensi dan pernyataan tentang manajemen perencanaan KONI Pematang Siantar di atas dalam kategori baik. Ini dibuktikan dengan hasil pengujian analisis deskriptif frekuensi dari 30 jumlah responden dengan jumlah pertanyaan sebanyak 7 soal dan diperoleh skor sebesar 604 dengan nilai persentase 71,9\%. Dengan dasar inilah peneliti menyimpulkan bahwa manajemen perencanaan KONI Pematang Siantar dikategorikan dalam kategori baik.

b. Analisis Deskriptif Manajemen Pengorganisasian KONI Pematang Siantar

Tabel 3

Deskripsi Tanggapan Responden Terhadap Manajemen Pengorganisasian

\begin{tabular}{cccc}
\hline $\begin{array}{c}\text { JUMLAH } \\
\text { RESPONDEN }\end{array}$ & $\begin{array}{c}\text { JUMLAH ITEM } \\
\text { PERNYATAAN }\end{array}$ & TOTAL SKOR & $\begin{array}{c}\text { PERSENTASE } \\
(\boldsymbol{\%})\end{array}$ \\
\hline 30 & 6 & 568 & 78,89 \\
\hline
\end{tabular}

Berdasarkan tabel di atas rangkuman rekapitulasi hasil deskriptif frekuensi dan pernyataan tentang manajemen pengorganisasian KONI Pematang Siantar di atas dalam kategori baik. Ini dibuktikan dengan hasil pengujian analisis deskriptif frekuensi dari 30 jumlah responden dengan jumlah pertanyaan sebanyak 6 soal dan diperoleh skor sebesar 568 dengan nilai persentase $78,89 \%$. Dengan dasar inilah peneliti menyimpulkan bahwa manajemen pengorganisasian KONI Pematang Siantar dikategorikan dalam kategori baik.

c. Analisis Deskriptif Manajemen Pelaksanaan KONI Pematang Siantar

Tabel 4

Deskripsi Tanggapan Responden Terhadap Manajemen Pergerakan

\begin{tabular}{cccc}
\hline $\begin{array}{c}\text { JUMLAH } \\
\text { RESPONDEN }\end{array}$ & $\begin{array}{c}\text { JUMLAH ITEM } \\
\text { PERNYATAAN }\end{array}$ & TOTAL SKOR & $\begin{array}{c}\text { PERSENTASE } \\
(\boldsymbol{\%})\end{array}$ \\
\hline 30 & 5 & 510 & 85 \\
\hline
\end{tabular}


Berdasarkan tabel di atas rangkuman rekapitulasi hasil deskriptif frekuensi dan pernyataan tentang manajemen pergerakan KONI Pematang Siantar di atas dalam kategori sangat baik. Ini dibuktikan dengan hasil pengujian analisis deskriptif frekuensi dari 30 jumlah responden dengan jumlah pertayaan sebanyak 5 soal dan diperoleh skor sebesar 510 dengan nilai persentase 85\%. Dengan dasar inilah peneliti menyimpulkan bahwa manajemen pergerakan KONI Pematang Siantar dikategorikan dalam kategori sangat baik.

d. Analisis Deskriptif Manajemen Pengendalian KONI Pematang Siantar

Tabel 5

Deskripsi Tanggapan Responden Terhadap Manajemen Pengendalian

\begin{tabular}{|c|c|c|}
\hline $\begin{array}{cl}\text { JUMLAH } & \text { JUMLAH ITEM } \\
\text { RESPONDEN } & \text { PERNYATAAN }\end{array}$ & TOTAL S & $\begin{array}{c}\text { PERSENTASE } \\
(\%)\end{array}$ \\
\hline \begin{tabular}{l|l}
30 & 6 \\
\end{tabular} & 747 & 88,93 \\
\hline
\end{tabular}

Berdasarkan tabel di atas rangkuman rekapitulasi hasil deskriptif frekuensi dan pernyataan tentang manajemen pengawasan/KONI Pematang/Siantar di atas dalam kategori sangat baik. Ini dibuktikan dengan hasil pengujian analisis deskriptif frekuensi dari 30 jumlah responden dengan jumlah pertanyaan sebanyak 6 soal dan diperoleh skor sebesar 747 dengan nilai persentase 88,93\%. Dengan dasar inilah peneliti menyimpulkan bahwa manajemen pengawasan KONI Pematang Siantar dikategorikan dalam kategori sangat baik.

e. Analisis Deskriptif Manajemen Pembinaan Olahraga Prestasi KONI Pematang Siantar

Tabel 6

Deskripsi Tanggapan Responden Terhadap Manajemen Pembinaan Olahraga Prestasi

\begin{tabular}{cccc}
\hline $\begin{array}{c}\text { JUMLAH } \\
\text { RESPONDEN }\end{array}$ & $\begin{array}{c}\text { JUMLAH ITEM } \\
\text { PERNYATAAN }\end{array}$ & TOTAL SKOR & $\begin{array}{c}\text { PERSENTASE } \\
(\boldsymbol{\%})\end{array}$ \\
\hline 30 & 25 & 2429 & 81,18 \\
\hline
\end{tabular}

Berdasarkan tabel di atas rangkuman rekapitulasi hasil deskriptif frekuensi dan pernyataan tentang Manajemen Pembinaan Olahraga Prestasi KONI Pematang Siantar terhadap 4 indikator di atas dalam kategori sangat baik. Ini dibuktikan dengan hasil pengujian analisis deskriptif frekuensi dari 30 jumlah responden dengan jumlah pertanyaan sebanyak 25 soal dan diperoleh skor sebesar 2429 dengan nilai persentase 81,18\%. Dengan dasar inilah peneliti menyimpulkan bahwa Manajemen Pembinaan 
Olahraga PrestasiKONI Pematang Siantar terhadap 4 indikator dikategorikan dalam kategori sangat baik.

\section{PEMBAHASAN PENELITIAN}

Setelah dilaksanakan penelitian di KONI Pematang Siantar yang diawali dengan pengambilan data validasi angket di KONI Binjai, diperoleh hasil persentase dan keterangan dari tiap indikator Analisis Manajemen Pembinaan Olahraga Prestasi di KONI Pematang Siantar sebagai berikut :

a. Skor tertinggi berdasarkan indikator pengendalian dengan keterangan sangat baik dengan persentase $88,93 \%$, sedangkan skor terendah dari indikator perencanaan dengan keterangan baik dengan persentase $71 \%$.

b. Skor tertinggi berdasarkan angket Analisis Manajemen Pembinaan Olahraga Prestasi di KONI Pematang Siantar dengan keterangan sangat baik dan skor terendah juga dengan keterangan baik.

Data tentang Analisis Manajemen Pembinaan Olahraga Prestasi di KONI Pematang Siantar :

a. Perencanaan (planning), dengan keterangan baik . Aspek ini mencerminkan dalam pembinaan olahraga prestasi, perencanaan (planning), merupakan hal yang sangat dibutuhkan, menurut Terry (2012:17) perencanaan adalah menetapkan pekerjaan yang harus dilaksanakan oleh sekelompok untuk mencapai tujuan yang digariskan.. Berdasarkan hasil penelitian yang telah dilakukan di KONI Pematang Siantar pihak KONI selalu memberikan informasi tentang tujuan didalam pembinaan olahraga prestasi serta perencanaan yang ditetapkan saling memiliki keterkaitan. KONI Pematang Siantar selalu melibatkan pengcab dalam penyusunan kebijakan pembinaan dan memiliki program dalam mengatasi masalah didalam pembinaan olahraga prestasi. Namun, KONI Pematang Siantar tidak memiliki perencanaan yang sistematis dan program berjenjang dalam meningkatkan olahraga prestasi serta tidak memiliki perencanaan sumber dana yang didatangkan untuk pembinaan olahraga prestasi. Hal inilah yang menyebabkan persentase manajemen perencanaan KONI Pematang Siantar paling rendah diantara indikator lainnya.

b. Pengorganisasian (organizing), dengan keterangan baik. Pengorganisasian merupakan hal yang mendukung dalam pembinaan olahraga prestasi terutama pada KONI. Berdasarkan hasil penelitian di KONI Pematang Siantar setiap bidang dalam 


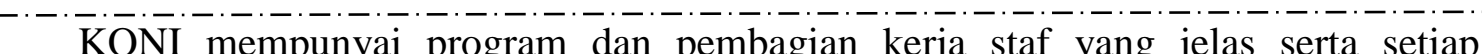
Kent mempunyai program dan pembagian kerja staf yang jelas serta setiap pengurus mengetahui mekanisme kerja masing-masing bidang. Pengorganisasian ini memang akan sulit dilakukan karena tenaga kerja yang kurang dari latar belakang olahraga, tetapi KONI Pematang Siantar ini tetap memberdayakan orangorang yang ada dengan maksimal.

c. Pergerakan (actuating), dengan keterangan sangat baik. Berdasarkan hasil penelitian di KONI Pematang Siantar, seluruh jajaran KONI Pematang Siantar selalu menjaga komunikasi dan hubungan yang harmonis agar perintah, laporan, informasi, berita dan saran dapat diterima dengan baik sehingga terjalin kerjasama antar pengurus dalam melakukan kegiatan. Di KONI Pematang Siantar ini pimpinan sebagai penggerak kegiatan selalu memantau dan memotivasi bawahan yang akan bekerja sehingga setiap orang bekerja dengan mkasimal dengan tanggungjawab yang diemban.

d. Pengendalian (controlling), dengan keterangan sangat baik . Berdasarkan hasil penelitian di KONI Pematang Siantar, KONI selalu melibatkan pengurus dalam diskusi penting dan memberitahu tentang adanya kemajuan program kerja didalam upaya pembinaan olahraga prestasi. KONI selalu mengawasi pelaksanaan dan kegiatan anggotanya dalam pelaksanaan program latihan. Namun, pihak KONI tidak melakukan pengawasan dalam perekrutan pelatih dan atlet karena hal tersebut dilakukan oleh pengcab.

\section{KESIMPULAN}

Manajemen pembinaan olahraga prestasi di KONI Pematang Siantar 4 (empat) indikator (fungsi manajemen) dalam keadaan sangat baik.

\section{Daftar Pustaka}

Arikunto, (2002). Manajemen Penelitian. Jakarta : PT. Rineka Cipta Harsuki, (2013), Pengantar Manajemen Olahraga, Jakarta : Rajawali Pers Husdarta, H. (2012). Manajemen Pendidikan Jasmani. Bandung: Alfabeta. Paturusi, Ahmad. 2012. Manajemen Penjas dan Olahraga. Jakarta:Rineka Cipta. Rosdiani, Dini. (2012). Dinamika Olahraga dan Pengembangan Nilai. Bandung: Alfabeta.

Siagian, P. Sondang. (2005). Fungsi-fungsi Manajerial. Jakarta: Bumi Aksara. Sudjana, (1996). Metode Statistika, Bandung : Tarsito 